\title{
Migratory behaviour of displaced homing yellow eels (Anguilla anguilla) in the North Sea
}

\author{
F.-W. TeSCH \\ Biologische Anstalt Helgoland (Zentrale); \\ Hamburg, Federal Republic of Germany
}

\begin{abstract}
KURZFASSUNG: Das Wanderverhalten verpflanzter und heimfindender Gelbaale (Anguilla anguilla) in der Nordsee. Vier Gelbaale (Anguilla anguilla L., standorttreue Entwicklungsform) wurden aus dem Gebiet des Limfjordes in die Deutsche Bucht oder in die Mittlere Nordsee verpflanzt, mit Ultraschallsendern markiert und nach dem Aussetzen 7 bis 35 Stunden verfolgt. Sie schwammen meistens auf einem Kompaßkurs in südöstlicher Richtung $\left(140^{\circ}\right)$. Der mittlere Kurs dieser und vier weiterer, schon früher untersuchter Gelbaale betrug $126^{\circ}$. Das beobachtete Heimfindeverhalten entspricht den Ergebnissen früherer Untersuchungen mit konventionell markierten Aalen. Die errechnete Schwimmgeschwindigkeit betrug $1,5 \mathrm{~km} / \mathrm{h}$ und lag unter der Geschwindigkeit der früher untersuchten Exemplare. Markierung mit einem druckmessenden Ultraschallsender lieferte vorläufige Daten über die Schwimmtiefe; sie lag zwischen 4 und $18 \mathrm{~m}$, während die Wassertiefe $41 \mathrm{~m}$ betrug. Es wird diskutiert, wie die Aale Untiefen der Küstengebiete meiden.
\end{abstract}

\section{INTRODUCTION}

In a number of tagging and transplantation experiments yellow (stationary) eels exhibited the ability of homing when displaced for more than $100 \mathrm{~km}$ (cf. TEsCH, 1973, pp. 167-171). Successful homing was performed in rivers and in open sea areas. The mechanism of orientation in homing eels as well as in other species is unknown. Although investigations on this topic using the conventional tagging method may rarely yield further essential results, field studies are necessary to elucidate behaviour during the search for the home area.

Promising initial experiments have started applying the technique of tracking eels tagged by ultrasonic transmitters ('ТеsсH, 1974a). Eels captured in the Elbe estuary, as well as specimens from the Baltic, released East of the island of Helgoland (North Sea) were tracked following a South-East direction towards the German mainland, the reverse to that exhibited by migratory silver eels (TEsch, 1974a). This behaviour would soon have guided the Elbe estuary specimens to their home area South-East of the releasing point. To examine if this South-East trend would also occur in the eels originating from a home area located farther North, four Limfjord specimens were released for tracking in two different places of the North Sea. 
In order to obtain data on swimming depth, a pressure sensing transmitter (STASKo \& Rommer, 1974) was attached to one of the specimens.

\section{MATERIAL AND METHODS}

All four specimens (Nos. V-VIII in continuation of the earlier experiment, TESCH, 1974a) were female silver eels and derived from commercial catches of the Limfjord region (Denmark): located about $300 \mathrm{~km} \mathrm{NE}\left(10-40^{\circ}\right)$ of the different releasing points. The eels were captured one to three weeks in advance of the tracking experiments. Eels Nos. V, VII and VIII measured $80 \mathrm{~cm}$ in length and weighed $1000 \mathrm{~g}$ each, while No. VII measured $86 \mathrm{~cm}$ and weighed $1500 \mathrm{~g}$. Eels Nos. V and VI were released about $20 \mathrm{~km}$ WSW of the island of Helgoland. Eels Nos. VII and VIII were started SE of the White Bank, an area in the central NorthSea (position about $54^{\circ} 42^{\prime} \mathrm{N} 6^{\circ} 36^{\prime} \mathrm{E}$ ) less influenced by the tidal current than the Helgoland area (Fig. 1).

Three of the ultrasonic transmitter tags (TESCH, 1972, 1974a) with a power of 46 or $52 \mathrm{~dB}$ rel $1 \mu \mathrm{b}, 1 \mathrm{~m}$, were products of Smith Root Electronics (USA) (eels Nos. V,

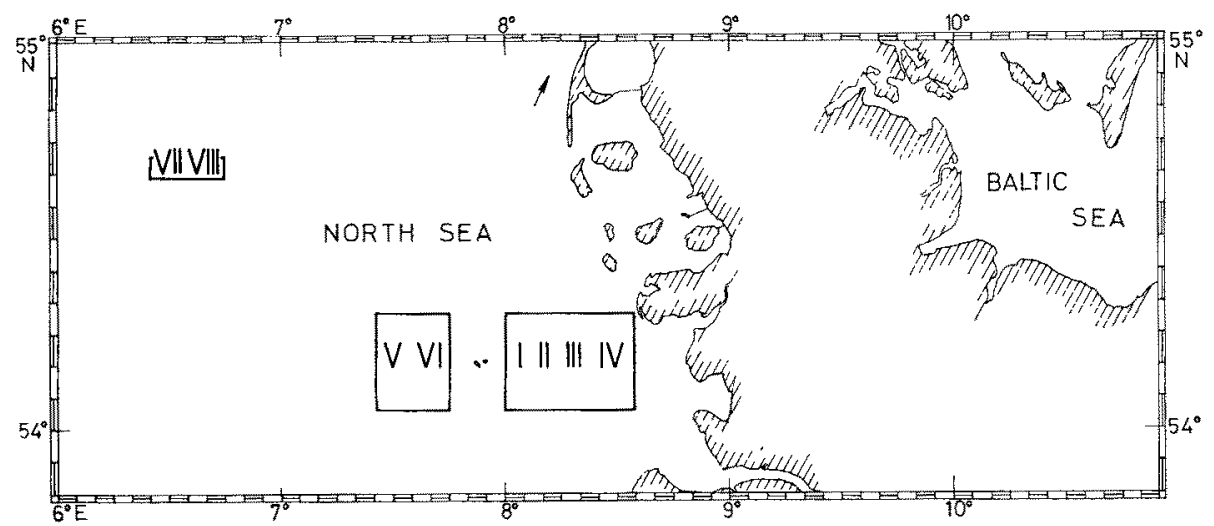

Fig, 1: Survey map with tracking areas and direction of Limfjord (arrow), the place of origin of the eels Nos. V-VIII. Eels Nos. I-IV from Tesch (1974a) are included

VI, VIII). Eel No. VII was equipped with a pressure sensing transmitter ( $\mathrm{p}-100)$ described by Stasko \& Rommel (1974), developed by the Electrical Engineering Department, University of New Brunswick, Fredericton, Canada and produced by Epitek Electronics, Canada. The transmitters were cylindrical $70 \times 16 \mathrm{~mm}$, weighing $30 \mathrm{~g}$ in air, using the frequency $70-74 \mathrm{kHz}$ and the pulse repetition rate, depending on depth, 60-300 pulses/min. The receiving system (Krupp-Atlas Elektronik, Germany) was the same as described earlier (Теsch, 1972, 1974a). It is equipped with a pulse filtering facility and during the tracking experiments was adjusted to a pulse duration of $40 \mathrm{msec}$ although the output of the pressure sensing transmitter amounted to $20 \mathrm{msec}$. Hence the range of the transmitter was only small compared to the other transmitters 
used in this study. Anaesthetising and affixation of the transmitter to the fish in front of the dorsal fin was done as described earlier (TEscH, 1974a).

The $38 \mathrm{~m}$ long R. V. "Friedrich Heincke" was used as tracking vessel. This is better fitted for longer cruises and bad weather conditions than the $24 \mathrm{~m}$ long vessel of the earlier experiments (TESCH, 1972, 1974a).

Duration of tracking for the different specimens was: No. V July 4, 1973, 8.56 to 16.32 ( 8 h); No. VI July 5, 1973, 9.11 to 15.45 ( $7 \mathrm{~h})$; No. VII July $10,16.40$ to July $11,1973(24 \mathrm{~h})$; No. VIII July $10,20.45$ to July $12,7.20$ (35 h). From the overlapping tracking time for Nos. VII and VIII, it is obvious that tracking of two eels occurred at the same time. In addition a third fish, a cod (Gadus morbua) not dealt with in this study, has been released and tracked. This simultaneous tracking of three fishes was possible because of a more stationary behaviour of two of the fishes. The weather was clear with wind not stronger than Beaufort force 2 during tracking courses V and VI; it was overcast during trackings VII and VIII with winds force 1 to 5 . The surface water temperature was approximately $18^{\circ} \mathrm{C}$ during all tracking experiments.

Net swimming direction and speed were determined as calculated earlier (TESCH, 1972, 1974a). Direction and speed of current during tracking experiments $V$ and VI were provided by measurements of the light ship "Deutsche Bucht"; for No. VIII values given by Neumann \& Meier (1964) were used. For No. VII no positions throughout the course were available. Hence only the connection between releasing point and last tracking positions indicated the swimming direction. This seems to be sufficient for a directional evaluation as this fish could be tracked for almost two tidal periods $(24.3 \mathrm{~h})$. Figure 2 presents the calculated swimming direction for each quarter of an hour for eels Nos. V, VI and VIII by the small arrow heads in the circles. The mean swimming direction resulted from calculation of the mean angle on the basis of these single values. The mean direction of all specimens is examined for significance by the Rayleigh test (BATSCHELET, 1965).

\section{RESULTS}

All four eels used in this tracking experiment generally preferred a South-East swimming direction, although from the true track this is not quite obvious (Fig. 2). The general directions taken by the four fishes were $134.5^{\circ}, 132.4^{\circ}, 147.0^{\circ}, 147^{\circ}$, respectively with a mean of $140.3^{\circ}$. Yellow eels in previous experiments in 1972 (Fig. 3) preferred $108.7^{\circ}$ not very different from that found in 1973. Although the 1972 specimens originated from a home area which was located further South than that of the 1973 yellow eels, they preferred a more easterly course. Because of the small sample sizes, this might be a chance difference. If the data from both experiments are pooled (Fig. 4), the mean direction of the eight specimens is $125.5^{\circ}$. By application of the Rayleigh test the concentration in the observed direction was significant (error $=1 \%$ ).

Calculated swimming speeds for eels No. V, VI and VIII were $0.696,0.74$ and $0.98 \mathrm{kn}$, respectively. The swimming speed of No. VII could not be determined for single positions, but overall speed was at least $0.95 \mathrm{kn}$. No. VIII, which was tracked 

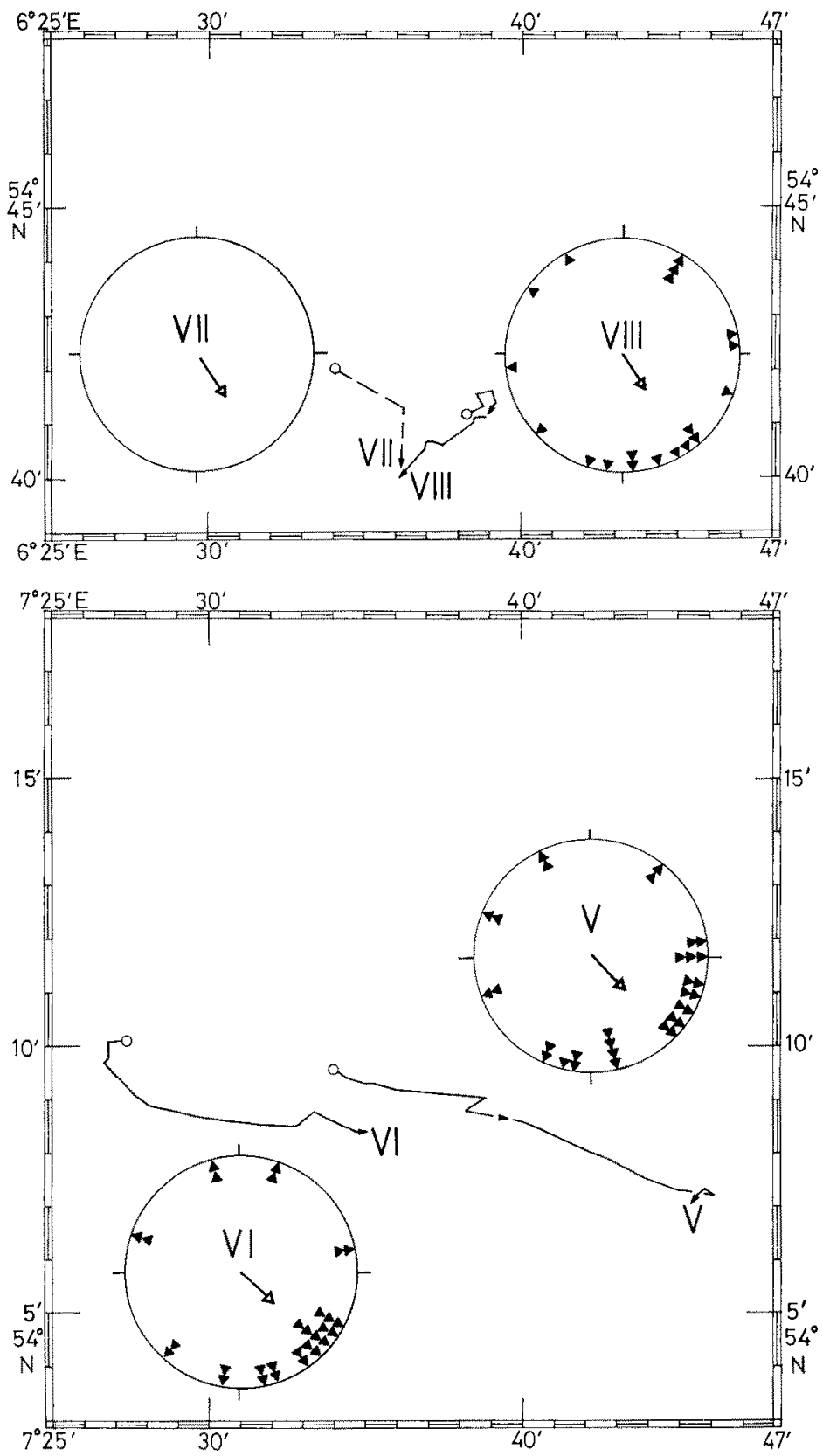

Fig. 2: Tracking courses and calculated swimming direction of the eels. Roman numbers: eels Nos. V-VIII; small circles: point of release; triangles in the compass circles: swimming direction of eels through the water calculated every $15 \mathrm{~min}$; arrow in centre of the compass circles: mean swimming direction; dashed tradking course (eel No. VII): single positions during tracking not known 


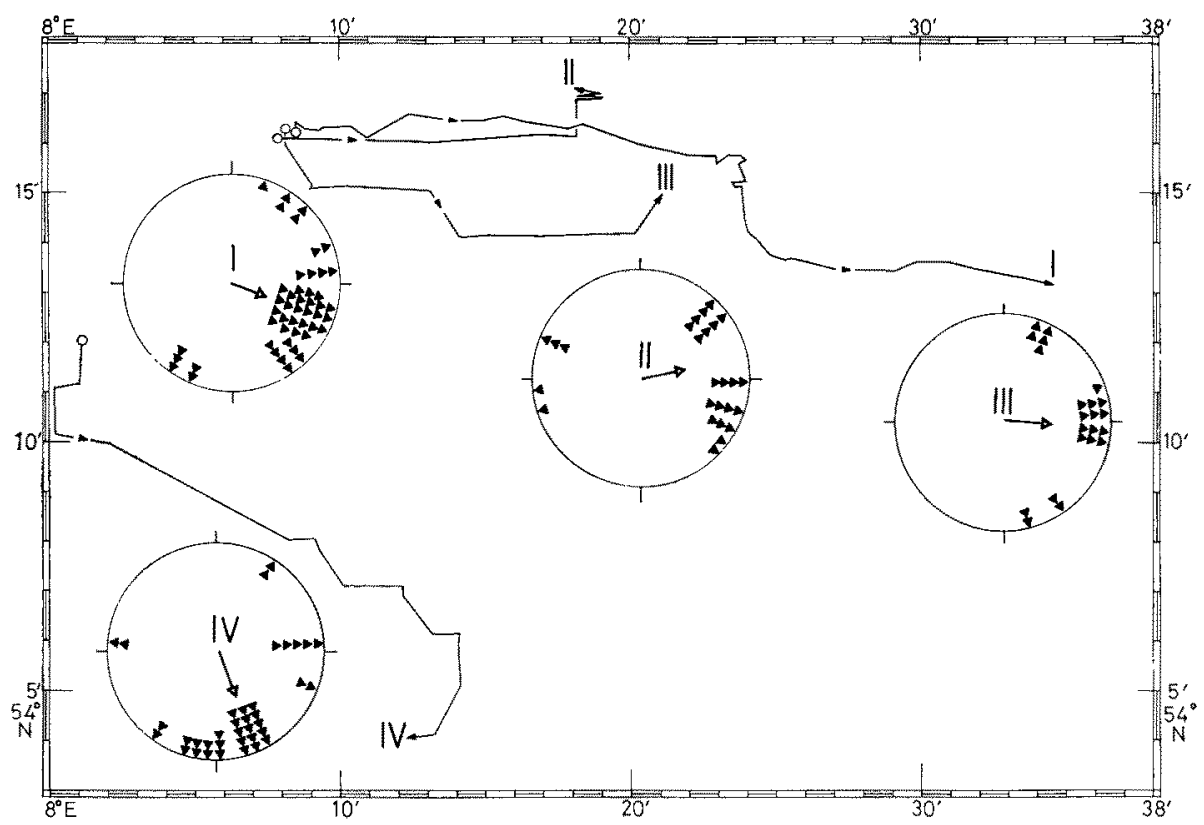

Fig. 3: Tracking courses and calculated swimming direction of eels Nos. I-IV (from TESCH, 1974a). Small circles: point of release; triangles in the compass circles: swimming direction of eel through the water calculated every $15 \mathrm{~min}$; arrow in centre of the compass circles: mean swimming direction
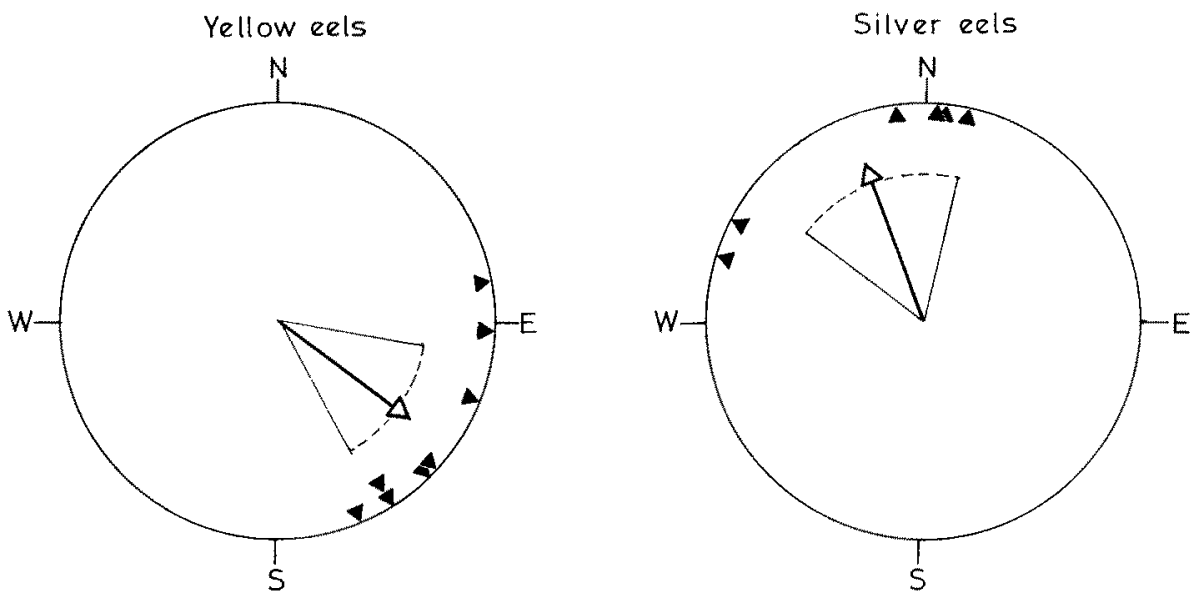

Fig. 4: Mean swimming direction (arrow) of the eight tracked yellow eels (left) compared with the mean swimming direction of six silver eels (right; after TesCH, 1974a). Triangles: swimming direction of the single eels; dashed lines: enclose the mean angular deviation of the circular distribution 
from 20.45 to $07.20 \mathrm{~h}$ the next day, became stationary after $5 \mathrm{~h}(1.40)$ and was abandoned $30 \mathrm{~h}$ later. The speed of the 1973 tracked eels was below the speed displayed by yellow eels investigated in 1972 (Tesch, 1974a), which swam an average of about $1.2 \mathrm{kn}$.

The preferred swimming depth of No. VII as indicated by a pressure sensing transmitter has been observed to be in upper water layers (Table 1). Only during the

Table 1

Swimming depth of yellow eel No. VII at the start of its course and at the end of the tracking experiment $24 \mathrm{~h}$ later. Water depth: $41 \mathrm{~m}$

\begin{tabular}{|ccc|}
\hline Date & Time & Swimming depth (m) \\
\hline July 10 & 16.40 & 11 \\
& 16.43 & 18 \\
July 11 & 16.46 & 4 \\
& 17.00 & 9 \\
& 17.11 & 8 \\
\hline
\end{tabular}

first minutes after release did the fish swim in medium water layers. Observations took place during daylight with the sky overcast. These results are preliminary because of the technically bad conditions of reception during tracking and the resulting comparatively short observation time.

\section{DISCUSSION}

The observations on the directional behaviour of displaced yellow eels in the open North Sea have confirmed earlier observations (TESCH, 1974a) that a SE compass course is taken. It now can be assumed that the eels do not migrate in the direction of their home area, which would require a more complicated mechanism of orientation, e. g. determination of longitude and latitude. Although the specimens used in this study originated from an area North of the releasing point, the SE tendency has not been affected. Conventional tagging experiments (e. g. TescH, 1967), which seemed to prove immediate heading of the homing yellow eels in the direction of the home area, were probably partly misinterpreted on finding that the eels' compass course pointed by chance in the direction of the home area. This would also be true for results of earlier tracking experiments with yellow eels I and II (Tesch, 1974a).

Analysis of the earlier long distance transplantation experiments with yellow eels tagged conventionally (Deelder \& Tesch, 1970), in view of above described observations, now renders explicable results: e. g. eels displaced from the Ijsselmeer dike to Helgoland (237 km NE) were recaptured in 1968 (50\%) and $1969(86 \%)$ South-East of Helgoland; eels displaced from the Ijsselmeer dike to Borkum (144 km NE) were recaptured $196973 \%$ South-East off Borkum (Figs. 4 and 7 in DEELDER \& TESCH, 1970). The homing direction in all three cases was South-West. If the home area were 
situated far East of the displacement point recaptures have been reported nearly $100 \%$ East to South-East of the displacement area (Fig. 8 and 9 in DeELder \& TESCH, 1970).

The evidence that not only silver eels but also yellow eels have a sense of compass direction (Fig. 4) has been supported by laboratory investigations (TESCH \& LELEK, 1973). In a circular tank the yellow eels preferred either South or North directions. Hence, if an eel is moved from a Northern area to Southern releasing point it might also migrate in Northern direction. Otherwise homing of yellow eels from the Elbe estuary to Helgoland (Tesch, 1967) would have been impossible.

My results are in accordance with behaviour exhibited by other displaced stationary fishes, e. g. Abramis brama, examined during field experiments by the float-tracking method (Poddunny, 1965). Of the displaced breams $87.5 \%$ moved along the magnetic meridian, of the non-displaced individuals only $50 \%$. Perhaps an Eastward or Northward orientation is a feature displayed also by spawning populations of the North American cutthroat trout (Salmo clarki): "the ability to maintain a constant compass direction until shore or bottom is available for cues and then paralleling the shoreline would be a considerable improvement over random search in homing from open water points..." (MCCLEAVE, 1967). In the described manner the compass course swimming is also useful as far as homing of displaced yellow eels is concerned.

How orientation works if the shoreline or the upper littoral is reached cannot be a matter for investigation in the North Sea costal areas. Tracking on the flat tidal area with the kind of vessel used in this study is impossible and smaller vessels are not fit for the North Sea. In the 1972 yellow eel tracking experiments (TEsCH, 1974a), when eel No. I reached the littoral zone, it chose a trench for further South-Eastern movement, confirming, in addition to the experiment with the pressure sensing transmitter, that a depth not less than $4 \mathrm{~m}$ is preferred. A silver (migratory) eel tracked in the littoral area of Helgoland preferred a trench as well (TEsch, 1972) and did not leave areas with water depths less than about $7 \mathrm{~m}$. Similarly silver eels, marked by surface floats, exhibited movement along the $5 \mathrm{~m}$ isobath in Kursk Lagoon of the Baltic Sea (OvcrinNIKov, 1971). Hence yellow eels homing during daylight seem to be deflected from the coast by depths less than $4 \mathrm{~m}$, while silver eels seem to prefer still deeper water. The releaser for a change in swimming direction might be bottom contact and the sensing of depth dependent on pressure or light intensity. Tracking experiments along coast lines during daylight and in darkness and the application of pressure sensing transmitters could assist in answering these questions.

The exhibited behaviour of eel No. I (TEsch, 1974a) - to swim in a deep channel would not have led that specimen to its home area in the Elbe estuary but to a different estuary located farther North. As we know from tagging experiments (TEsCH, 1970; VLADIKOv, 1971), transplanted yellow eels avoid foreign estuaries but succeed in finding their home estuary. Hence additional orientation mechanisms must be involved. Similarly, as in salmonids, the smell of the home river could play a role in homing yellow eels although in this respect earlier investigations (ТEscH, 1970) gave no positive result.

It is astonishing that homing yellow eels, which are usually bottom animals, prefer upper water layers during migration. However the small amount of available observations has to be confirmed by further investigations. Silver eels (Anguilla rostrata and 
A. anguilla) prefer upper water layers as shown by pressure sensing transmitters STAsKo \& Rommel, 1974; Tesch, unpubl.) although frequent diving of silver eels into greater water depth, partly to the bottom, seems to indicate different behaviour compared to yellow eels.

Only one of the eight tracked yellow eels stopped its migration and obviously took to the bottom for more than $30 \mathrm{~h}$. After that time observation was discontinued. Yellow eels transplanted over long distances, forced to swim for a long time through a very monotonous environment, perhaps stop once and settle down, adapting to the new environment.

Possible stimulation responsible for compass course swimming has been investigated on silver eels by laboratory experiments (Tesch, 1974b). From the results it seems obvious that the geomagnetic field is responsible, and it appears from the present study and earlier investigations on the directional behaviour of silver and yellow eels (TESCH \& LeLEK, 1973) that there exist many similarities in these two developmental stages of Anguilla anguilla as far as their orientational behaviour is concerned. Hence the ability of keeping compass direction by means of the geomagnetic field also seems to be a capacity of yellow eels.

\section{SUMMARY}

1. Four yellow (stationary) eels (Anguilla anguilla L.) were transplanted from Northern Denmark to the German Bight and to the central North Sea about $300 \mathrm{~km} \mathrm{SSW}$ of the home area. They were tagged with ultrasonic transmitters and tracked for 7 to 35 hours.

2. The mean direction adopted by the four individuals was $\mathrm{SE}\left(140^{\circ}\right)$, away from the direction of the home area (NNE). One eel discontinued activity after $5 \mathrm{~h}$ of active swimming. Combined with earlier tracking results on yellow eels a significant directional choise of $126^{\circ}$ is calculated; it is concluded that a South-Eastern or perhaps a North-Western compass course is the first swimming performance of yellow eels towards home, regardless of the direction of their home area.

3. Earlier results with conventionally tagged yellow eels transplanted over long distances have also shown a South-Eastern trend and are now explainable.

4. With a mean migratory speed below $1 \mathrm{kn}(1.85 \mathrm{~km} / \mathrm{h})$, the experimental specimes moved more slowly than individuals tracked one year previously in similar experiments.

5. One yellow eel tagged with a pressure sensing ultrasonic transmitter got lost twice because of an insufficently adjusted receiver. During the first minutes of tracking it preferred a depth between 4 and $18 \mathrm{~m} ; 24 \mathrm{~h}$ later it swam in a depth of 7 to $9 \mathrm{~m}$. The water depth was $41 \mathrm{~m}$.

6. From the discussion it becomes evident that yellow as well as silver eels prefer trenches if water depth decreases. Upon arrival in inshore waters directional behaviour in yellow eels probably might change; at daylight a minimum water depth of about $4 \mathrm{~m}$ is preferred. 
Acknowledgements. The author is indebted to Dr. E. HAGMeIER for arrangement of the cruises, to Captain T. Hornsmann and the crew of R. V. "Friedrich Heincke" for nautical managements, to Ms. M. BARTel and Mr. J. Marschall for technical assistance during preparation of the drawings and the manuscript, and to Dr. J. D. MCCleAve for critically reading the manuscript.

\section{LITERATURE CITED}

Batschelet, E., 1965: Statistical methods for the analysis of problems in animal orientation and certain biological rhythms. Am. Inst. biol. Sci., Washington, $57 \mathrm{pp}$.

Deelder, C. L. \& TESCH, F.-W., 1970: Heimfindevermögen von Aalen (Anguilla anguilla), die über große Entfernungen verpflanzt worden waren. Mar. Biol. 6, 81-92.

McCleave, J. D., 1967: Homing and orientation of cutthroat trout (Salmo clarki) in Yellowstone Lake, with special references to olfaction and vision. J. Fish. Res. Bd Can. 24, 2011-2044.

Neumann, H. \& MeIer, C., 1964: Die Oberflächenströme in der Deutschen Bucht. Dr. hydrogr. Z. 17, 1-40.

Ovchinnikov, V. V., 1971: The influence of hydrobiological factors upon the orientation of European eel (Anguilla anguilla L.). Coun. Meet. int. Coun. Explor. Sea (= C.M.-I.C.E.S.) M 12,1-2.

PoDdunny, A. G., 1965: Some results of remote observations on the behaviour of migrating fishes (in Russ.). In: Bionika. Nauka Jzd., Moscow, 255-263.

Stasko, A. B. \& Rommel, S. A., 1974: Swimming depth of adult American eels (Anguilla rostrata) in a salt water bay as determined by ultrasonic telemetry. J. Fish. Res. Bd Can. 31, 1184-1150.

Tesch, F.-W., 1967: Homing of eels (Anguilla anguilla) in the Southern North Sea. Mar. Biol. 1, 2-9.

- 1970: Heimfindevermögen von Aalen Anguilla anguilla nach Beeinträchtigung des Geruchssinnes, nach Adaptation oder nach Verpllanzung in ein Nachbar-Astuar. Mar. Biol. 6, 148-157.

- 1972: Versuche zur telemetrischen Verfolgung der Laichwanderung von Aalen (Anguilla anguilla) in der Nordsee. Helgoländer wiss. Meeresunters. 23, 165-183. [Experiments on telemetric tracking of spawning migration of eels (Anguilla anguilla) in the North Sea. Fish. Res. Bd Can. Transl. Ser. 2724, 1-29.]

- 1973: Der Aal. Parey, Hamburg, 306 pp.

- 1974a: Speed and direction of silver and yellow eels, Anguilla anguilla, released and tracked in the open North Sea. Ber. dt. wiss. Kommn. Meeresforsch. 23, 181-197.

- 1974b: Influence of geomagnetism and salinity on the directional choice of eels. Helgoländer wiss. Meeresunters. 26, 382-395.

- \& Lelek, A., 1973: Directional behaviour of transplanted stationary and migratory forms of the eel, Anguilla anguilla, in a circular tank. Neth. J. Sea Res. 7, 46-52.

Vladikov, V. D., 1971: Homing of the American eel, Anguilla rostrata, as evidenced by returns of transplanted eels in New Brunswick. Can. Fld Nat. 85, 241-248.

Author's address: Dr. F. W. TESCH

Biologische Anstalt Helgoland (Zentrale)

D-2 Hamburg 50

Palmaille 9

Federal Republic of Germany 